\title{
Chapter 4 \\ Desafío TEP - Positive Educational \\ Trajectories. A Public-Private Alliance to Strengthen Public Education During the Pandemic
}

\author{
Juan Pablo Valenzuela and Simon Rodriguez
}

\begin{abstract}
This case study describes the Desafío TEP project, which arose from a public-private alliance between the Arauco Educational Foundation, the Center for Advanced Research in Education (CIAE) from the University of Chile, and the Andalién Sur Local Public Education Service (SLEP). The goal of the project is to develop a model for the prevention of school exclusion (resulting from repetition and dropout) in public schools.

Although the initiative was in consideration to be suspended due to the closure of schools across the country caused by COVID-19, instead the proposal was completely redesigned, recognizing that the pandemic would increase the problems of school exclusion. The innovations generated in this redesign are anticipated to lead to long-term sustainability and scalability in the region through cost reductions and the promotion of remote interactions between different establishments working in networks, such as the SLEP, the schools, and the teams from the CIAE and Arauco Educational Foundation. This network is further supported by the actors in the educational system of the territory.
\end{abstract}

Support from ANID/PIA/Basal Funds for Centers of Excellence FB0003 is gratefully acknowledged.

Support from Arauco to promote Desafío TEP pilot, developed by Fundación Educacional Arauco (Arauco Educational Foundation).

\footnotetext{
J. P. Valenzuela

Instituto de Educación \& CIAE, Universidad de Chile, Santiago, Chile

S. Rodriguez $(\square)$

Fundación Educacional Arauco. Universidad Diego Portales, PhD Program in Education

UDP - UAH, Santiago, Chile

e-mail: simon.rodriguez@ arauco.com
} 


\subsection{The Universidad of Chile and Its Support to Schooling System in the COVID-19 Context}

Founded in 1842, the University of Chile is the oldest, most recognized national and public institution of higher education in the country. Its mission involves a commitment to excellence in educating people and the vocation to contribute to the spiritual and material development of the nation. The university fulfills its mission by building leadership in the innovative development of the sciences and technologies, humanities, and the arts as well as through teaching, creating, and extending knowledge with a special emphasis on research and graduate studies (Universidad de Chile, 2020). Located in Santiago, the country's capital, the University of Chile has more than 42,000 undergraduate and graduate students. It has 14 faculties and 5 specialized institutes, one of which is the Institute for Advanced Studies in Education (IE). IE was created in 2018, and the Center for Advanced Research in Education (CIAE), created in 2008, is part of IE. The University of Chile has the highest scientific productivity in the country, producing more than $30 \%$ of all national research.

The vision of the University for the next decade is to enhance its role as a national and state university to address challenges in higher education in research, creation, dissemination, outreach, and connectedness to the service of the country. It aims to do so in a socially critical and ethically responsible manner and with high levels of quality, pluralism, and social and gender equity. This vision expands the role of the state education system to have a prominent role in Latin American and international university networks, particularly with public universities. Additionally, its mission includes a strong commitment to culture, public education, and the schooling system. In particular, the mission declares that "it is the responsibility of the University to contribute the development of cultural heritage and national identity and to the improvement of the country's educational system" (Universidad de Chile, 2020).

The University of Chile is directly participating in several initiatives aimed at supporting schools from primary and secondary education in the context of the COVID-19 pandemic. On the one hand, the President of the University of Chile and the President of the Pontifical Universidad Católica de Chile participate in the Social Round Table to support the Ministry of Health coordinate general support actions and national policies to contain the effects of the pandemic. Both universities set up and led an alliance of research centers and researchers in the country to support the whole school system in various domains. Also, these leading initiatives motivated public discussions about educational challenges created by the pandemic across the country, such as Hablemos de Educación (Let's Talk About Education). Furthermore, the Network Information Center of Chile (NIC), an entity of the University of Chile in charge of managing Internet domains in the country, has been the distribution channel of the national educational curriculum to students and schools of the territories without Internet connectivity in the country. This has allowed the delivery of this material to 130,000 children ( $4 \%$ of the total number of students in the country) from 115 of 345 different municipalities. 
In another context, the University of Chile is also collaborating with different public institutions and private foundations to create initiatives related to the development of capacities for educational improvement at schools and the intermediate levels responsible for them, especially those in charge of public education in the country. One of these initiatives, adapted to the context of COVID-19, is the TEP Challenge (Positive Educational Trajectories), which the next section describes in detail.

\subsection{Desafío TEP. A Public-Private Alliance to Reduce Exclusion in Public Schools}

This case study describes the Desafío TEP project, which arose from a publicprivate alliance between the Arauco Educational Foundation, the Andalién Sur Local Public Education Service (SLEP), and the Center for Advanced Research in Education (CIAE). ${ }^{1}$ This alliance is promoted by the current government and framed under a public-private initiative called Compromiso Pais. The goal of the project is to develop a model for the prevention of school exclusion (repetition and dropout) in public schools. Desafío TEP is financed with resources from a national private company (Arauco), its educational foundation, and non-monetary resources from CIAE.

Arauco Educational Foundation is a private, non-profit foundation that has supported educational communities in the south-central region of the country since 1989, with a primary focus on public education. Its mission is to contribute to giving greater development opportunities to children and young people through education. For this, it deploys different lines of work, the main one being the development of educational and cultural improvement programs. Their motto is: "We believe in teachers."

CIAE is a research center located in the University of Chile. CIAE seeks to generate evidence, through $R \& D$, to support educational improvement. For the last 2 years, CIAE has studied factors, strategies, and best practices to reduce school exclusion.

The Andalién Sur Local Service of Public Education (SLEP) is one of the first 11 SLEPs in charge of public education. Since March 2020, Andalién Sur SLEP provides education to more than 17,000 students, most of them with low socioeconomic status (SES), in 83 PreK-12 schools located in 4 different counties of the south-central area of the country (Concepción, Chiguayante, Florida, and Hualqui).

Desafío TEP constitutes a pilot initiative to follow the educational path and reduce school exclusion in 12 of the Andalién Sur SLEP schools. The project design allows for continuous improvement processes before scaling up to the rest of the schools and replicating the experience in other SLEPs in the country.

\footnotetext{
1 “Desafío TEP” project team: Isidora Recart, Juan Pablo Valenzuela, Giulietta Vaccarezza, Simón Rodriguez, Millycent Contreras, Karla Escare, Lorena Peñailillo, Cristian Cardenas.
} 


\subsubsection{An Initiative in the Context of a New Public Education System}

In Chile, there is an enormous dissatisfaction with the public education system due to the low share of students it enrolls, low levels of performance, and difficulty in sustaining processes of improvement, as well as deficient management of financial, human resources, and challenges with transparency. For these reasons, a new institutional framework for public education was approved in 2017. Between the years 2018 and 2025, public education will be transferred from 345 municipalities to 70 new public entities-SLEPs. SLEPS will be responsible for managing and improving the quality of preschool, primary, and secondary public education, covering $36 \%$ of students in the country at the end of this period (Bellei, 2018; Uribe et al., 2019).

This focus on school exclusion is intentional; it seeks to respond to one of the challenges included in Law 21.040 (2017) of public education reforms. This reform indicates that one of the functions of the SLEP is to strengthen the Educational Trajectories of each student, which means to avoid school exclusion (preventing grade repetition and dropout) for every student in its territory by developing information systems and support programs that ensure every child and young person has a sustained and quality education from their initial education until the end of secondary level.

From June to December 2019, this alliance designed and prepared a pilot plan to begin to be implemented in 12 schools for the 2020 school year. In 2019, these schools enrolled 5,068 students.

\subsection{Desafío TEP Proposal}

In conceptual terms, the "educational trajectories" in TEP refer to the year-by-year performance of each student throughout their schooling, observing their starting point, educational experience, and results of their learning that materialize in their academic progression on this path (OEI, 2015). The additional adjective of "positive" comes from the emphasis on the strengths and resources that mobilize and improve school commitment as well as the generation of strong personal relations with each student. At the same time, this term focuses on the development of capacities from existing resources, prioritizing the generation of robust evidence and integrating the most effective methodologies and strategies learned for this objective. Finally, this development of capacities is located within the intermediate levels, such as schools and work teams of the school system, so that educational organizations can promote the trajectories for every student (Recart et al., 2020).

The theory of change of the initiative states that if capacities for collaboration between and within schools are developed, decisions are made based on data, and leadership and management of processes and practices are mobilized, then 
strategies will be implemented which will increase student attendance, school commitment, and student engagement, lowering grade retention and repetition.

The strategy for capacity development is based on action-based learning. The planning, implementation, and learnings of "TEP challenges" are raised and developed by multidisciplinary leading teams from the participating schools and then evaluated in each context in terms of their urgency and relevance. In turn, both the technical advisers belonging to the SLEP and the leading teams participate in three "micro-networks," each one formed by four schools with different characteristics, to promote learning across schools. These "micro-networks" identify best practices and participate in workshops to develop knowledge that enhances the mobilization of skills and practices.

\subsection{The Desafío TEP Design and Its Modifications in the COVID-19 Context}

The interruption of face-to-face classes led to the suspension of this initiative for 2 weeks in March 2020. Schools and the Andalién Sur SLEP needed to reorganize their teachers and staff to the new context as well as devote attention to actions related to health and social issues for families and students.

Within these first 2 weeks, the team that coordinated this alliance held online meetings to review the continuity of the joint work. These meetings confirmed the shared vision that, in the context of the pandemic, it was even more relevant to maintain contact and engagement with students and families and promote their continuous school attendance and involvement. From the beginning, it was considered that the end of face-to-face classes implied an increased risk of excluding children from the system, especially those most vulnerable, which constitute the majority of the students enrolled in Andalién Sur.

Considering this renewed agreement, we implemented and adapted the following actions:

- Group meetings were held with management teams from all schools from Andalién Sur to hear and record the work that was being carried out directly along with its main challenges. From these meetings, we recognized the enormous effort and energy dedicated by schools in seeking to reorganize and regenerate pedagogical work with students and families.

- Together with technical advisers from the Andalién Sur SLEP, we decided to adjust the work cycle of the project for the group of 12 schools participating in this pilot stage. We focused on supporting the actions and strategies in a context with much more difficulties to connect between schools and families, going from a single cycle for the whole year in 2020 to two smaller cycles for the same period. Each cycle is focused around an urgent and relevant "TEP Challenge." This "TEP challenge" is based on an action hypothesis: a sequence of actions and results to be tested. The actions are put into practice and reviewed based on 
data they have and/or collected. It was proposed that the first cycle lasts 3 months, while the second cycle lasts 5 months. Emphasis is placed on "learn by doing" with the possibility of error and improvement being explicit. One lesson learned from this implementation period has been that the first cycle should be oriented toward a simple challenge, which will allow multidisciplinary leadership team (ELM) of each school to build confidence. Therefore, participants learn that it is possible to be successful in the context of virtual education within a short period. It is expected that for the following cycle, the challenge will increase in complexity.

- Micro-network online meetings were used as a strategy for capacity building, with a method that enhances the clarification and deepening of one's work and that of others. As a transversal tool for this cycle, the "TEP virtual notebook" and "TEP infographics" are being used, which seeks to document and organize the work carried out by each multidisciplinary leading team as well as resulting products that can be shared with different actors. This documentation and organization have both a descriptive and analytical level, considering two keys for its preparation: data analysis for decision-making and strategies implemented to address the identified challenge.

- Throughout the cycle, the focus on students with the highest risk of exclusion is made explicit. In the registration of the "TEP virtual notebooks" and the micronetwork online meeting, questions associated with data and actions for this target group of students are asked and processed.

- Considering that one of the keys is leadership and management that develops the Andalién Sur SLEP, planning and evaluation regarding each activity meeting took place with every participating technical advisor being present to strengthen the sustainability and scaling potential of this initiative. At the same time, "Whatsapp groups" were created between Arauco Educational Foundation, CIAE, and SLEP Andalién Sur to facilitate constant and fluent communication. All this has led to a manifestation of practices in two different dimensions that are needed to focus on follow-up work with schools teams: i) management of communication and structural conditions to foster micro-networks, which includes constant communication, scheduling of activities, and anticipation of necessary resources; ii) preparation and permanent review of facilitation with leading teams, which includes co-planning and co-evaluation together with cofacilitation of the implementation of the work and permanent training.

- We created an adapted monitoring system of the initiative. The key indicator of this initiative is "school engagement" (Saracostti, 2016). As a result, information related to "school engagement" is being collected. For each of the work activities with schools, an instrument of evaluation and satisfaction has been implemented, together with an analysis of the plans elaborated by the teams of the participating schools. Concerning monitoring capacity development, we applied an instrument to evaluate beliefs, knowledge, and practices to the issue of data-based decision-making, intra- and inter-school collaboration, leadership, and process management. This survey will be repeated at the end of the pilot phase to evaluate changes. 


\subsection{Learnings from the COVID-19 Context}

Since the suspension of face-to-face classes (early March) until July 2020, teams from SLEP and schools have participated in four micro-network online meetings, a coaching session with the leading team, and an online training workshop. These activities are prepared and evaluated jointly between CIAE, Arauco Educational Foundation, and Technical Advisors of the Andalién Sur SLEP.

Two dimensions of learning are recognized: those related to the model and method of work and those related to keys for the protection of positive school trajectories.

Regarding the first dimension, school leaders, teachers, and technical advisers identify that it is a "model of accompaniment that seeks to develop capacities, strengthening the dynamics of networking to explore their own challenges, related to the school trajectories of students, and address them jointly, supporting and nurturing the common and diverse elements" (TEP participant interview), being "fundamental to the TEP methodology the reflection and analysis of the teams, within a collaborative work framework" (TEP participant interview). In the methodological sense, they indicate that it implies the "identification of a specific problem related to this topic, analyze it following a reflective-participatory methodology and establish a plan to address its solution, always considering the importance of the use and generation of data to make decisions, and working on the method proposed by the companions of the project that is based on sharing experiences with other establishments that act as critical friends" (TEP participants focus group). In turn, the methodology "provides design tools and innovative digital tools that are easy to replicate" (TEP participants focus group). The reports of the activities indicate that $82 \%$ of the participants consider that what is reviewed in the online micro-networks is useful and contributes to the work of the establishment.

A specific learning in the context of a pandemic, which changed and will remain as part of the work of the Desafío TEP project team, is the mobilization of collaboration and promotion of equitable participation between and within teams. This is done through the use of tools and artifacts in synchronous and asynchronous environments. The possibility of working simultaneously and in a complementary way on a virtual device, which records and represents the elaboration and planning of a practice challenge, has promoted a "very efficient work strategy" (TEP participants focus group) and pertinent to schools. At the same time, it mobilizes a greater "fluidity" of the conversations and interactions between the different participants, be they teachers, school leaders, or system leaders, enhancing confidence and a "sense of security" to tackle complex issues.

Regarding the keys for the protection of positive school trajectories, the following lessons have been drawn from the content of the different "TEP virtual notebook": 


\subsubsection{Making Students Feel Competent and Secure}

Leading teams have identified that it is necessary and relevant for students to feel content and motivated in their activities so that they feel they are learning. Moreover, this will ensure that they successfully perform the tasks they are being required to do. This is not an easy task and has generated two great challenges in the work carried out by teachers:

a) Change, modify, and/or adjust learning resources.

b) Provide descriptive, individualized, and permanent feedback to students, highlighting progress and achievements to mobilize engagement.

\subsubsection{Socio-emotional Bond with Families and Students}

Considering the circumstances of social distancing and the uncertainties that they entail, the teams have identified the following needs:

- Diversification of channels and means to contact students and their families. Knowing the economic and social situation and environment of the students is key.

- Identifying risk factors to offer support in various forms. There are different kinds of risks, all of which are non-exclusive: i) material resources (water and electricity, connectivity, access to technological devices, geographical isolation); ii) sanitary and mental health of students and family; iii) the state of support networks and the need for emotional contention; iv) students that require permanent special educational needs (elaboration of specific resources in social distancing); and v) the situation of children and students that are currently the object of protective measures because their rights as children have been violated.

- Maintaining a permanent connection to parents and guardians. The role of parents and guardians in social distancing times is relevant. To this effect, "it is necessary to promote parents and guardian's engagement to promote student's engagement." As such, parents and guardians must become involved because they are valuable allies of the school's work. "If parents don't want to, their children will hardly want to."

- The key role of head-teachers. Teachers who are close to their students and show profound knowledge of everyone in their classroom are key. They help gather information and keep each student feeling noted and valued.

\subsubsection{Making Teachers Feel Competent, Safe, and Learning from Each Other}

The reorganization of labor that the pandemic has forced on schools has shown the importance of interprofessional and interdisciplinary collaboration between teachers. An example of this would be the collaborative work between teachers and 
educational psychologists or the pairing of a technologically savvy teacher with one that needs help in this area. These professional collaborations help build a feeling of security, competency, and learning in the understanding that there is much to be done and measures are being taken.

These measures have shown an interdependency with teachers supporting and teaching each other. The leading teams expect this will survive beyond the times of social distancing.

\subsubsection{Workplans in Social Distancing Must Be Based on Existing and Currently Used Technological Resources}

The lack of access and use of social media can further deepen inequalities in learning. Remote working is a gradual process, in which educational platforms must be known, familiarized, and progressively tested. In this context, teachers must start with the most popular platforms such as Facebook, Whatsapp, and Google Drive. In parallel, other resources such as learning capsules and specific educational platforms can be developed and trained for. This relates to the notion that teaching during social distancing has permanent and non-permanent features.

\subsubsection{Make Visible the Achievements of Students and Schools with a Focus on Comprehensive Care and Learning}

Multidisciplinary Leadership Teams and teachers mobilize the achievements of their students, requesting evidence (photographs, audio records, videos) in which they, together with their families, present how to carry out learning activities on various interests (musical, artistic, etc.). Parallel to this, they communicate the importance and need to take care of themselves, to be well and safe in their homes.

These actions seek to confront and/or reduce discourses that may negatively affect the school's trajectory. A clear example is the communications in secondary education, where students have declared that they will (possibly) opt for adult education (completing two grades in one year) in the year 2021, or that 2020 is a lost year in terms of learning.

\subsection{Sustainability and Projection}

The extension of the closure of face-to-face schooling in Chile motivated the Ministry of Education to convene a Commission of experts to prepare proposals to reduce the risk of further dropout in Chile. CIAE and Arauco Educational Foundation were invited to it given their experience in Desafío TEP. In July, the "Proposals for 
a Technical Table for the Prevention of School Dropout. For the timely detection of the risk of school exclusion and the construction of positive school trajectories for all children and young people" was published (MINEDUC, 2020), which included the practices developed in Desafío TEP.

Regarding the future, the Desafío TEP initiative is discussed in the Andalién Sur Development Plan for the coming years, so its expansion to the rest of the schools will continue in the following years. Also, the concept of TEP was included in the National Strategy to Strengthen Public Education elaborated by the Directorate of Public Education $(D E P)$ for the coming 8 years, and the initiative already has the support of DEP. This means that the learning model of TEP initiative has a high chance of being replicated in the rest of the SLEPs in the country.

Regarding the virtual methodology, both the leading teams and professionals in the SLEPs and the teaching teams in participating schools and institutions are continuing a majority of methods that were developed because they allow for the increased time dedicated to collaborative work and implementation, reducing transport fees for many professionals. Also, they will allow for an easier scaling-up of the initiative as the professionals involved in the SLEP Andalién Sur will be able to help other SLEPs in the country without leaving their local communities, as well as empowering micro-networking opportunities between SLEPs, professionals, and schools from different regions in the country, supporting the initiative in other SLEPs and schools. The learning and adjustments of Desafío TEP due to the pandemic will be integrated into the regular model in its expansion phase.

\section{References}

Bellei, C. (2018). Nueva Educación Pública. Contexto, contenidos y perspectivas de la desmunicipalización. CIAE - Universidad de Chile. LOM Editores, Santiago, Chile.

Ley 21.040 Crea el Sistema de Educación Pública. Biblioteca del Congreso Nacional de Chile. Consultado en agosto $2019 \mathrm{https}: / / \mathrm{www} \cdot$ leychile.cl/N?i=1111237\&f=2019-04-25\&p=

MINEDUC (2020). Propuestas mesa técnica para la prevención de la deserción escolar. Por la detección oportuna del riesgo de exclusión escolar y la construcción de trayectorias escolares positivas de todos los niños, niñas y jóvenes. Santiago, Chile. Avaliable in https://www.mineduc.cl/wp-content/uploads/sites/19/2020/07/propuestas_desercionescolar.pdf

OEI (2015). De la trayectoria en singular a las trayectorias en plural, en colaboración con Joana López, Buenos Aires.

Recart, I.; Valenzuela, J.P.; Vaccarezza, G.; Rodriguez, S.; Contreras, M.; Peñailillo, L.; \& Cardenas, C. (2020). Trayectorias Escolares Positivas: un desafío de calidad y equidad de las oportunidades educativas. Documento de trabajo. Available in https://www.fundacionarauco. cl/wp-content/uploads/2020/06/Trayectorias-Escolares-Positivas.-Desafio-calidad-y-equidadFinal.pdf

Saracostti, M. (2016). Manual de intervenciones sobre el compromiso escolar. Una variable clave para predecir procesos de desescolarización. Fondef id14|10078.

Universidad de Chile. (2020). Misión y visión estratégica de la Universidad de Chile. https://www. uchile.cl/portal/presentacion/institucionalidad/39635/mision-y-vision 
Uribe, M.; Valenzuela, J. P.; Anderson, S.; Cuglievan, G.; Núñez, I.; \& Hernández, C. (2019). Estudio de seguimiento y sistematización de procesos críticos en la transición de la gestión de la educación pública de los municipios a los Servicios Locales de Educación (SLEP). Universidad de Chile, Instituto de Estudios Avanzados en Educación (Santiago), \& Líderes Educativos: Centro de Liderazgo para la Mejora Escolar, Universidad Pontificia Católica de Valparaíso.

Valenzuela, J.P.; Ruiz, C.; \& Contreras, M. (2019). Revisión de antecedentes sobre exclusión educativa: una mirada a la deserción y repitencia escolar. Proyecto FONDEF IT17I1006 "Un sistema nacional de protección de trayectorias educativas: disminuyendo la exclusión educativa en la enseñanza escolar y previniendo la deserción en educación superior". CIAE, Universidad de Chile.

Juan Pablo Valenzuela is Full Professor from the Universidad de Chile and main researcher at the Institute of Advanced Studies in Education (IE) and the Center for Advanced Research in Education (CIAE), both from the same university; also he teaches at the Economics Department of the Universidad de Chile. He is a main researcher at the C-Lider, a leadership center for improvement education, where IE/CIAE collaborates with other national universities and research centers. He has a Bachelor degree in Economics from the Universidad de Chile and a Master and $\mathrm{PhD}$ degrees in Economics, from the University of Michigan, Ann-Arbor. He has published nationally and internationally several researches about school improvement on primary and secondary education, evaluation of public policies on the field, segregation analysis, public education reforms, and schooling leadership. During the pandemic he has participated in national commissions to improve students' retention and to support re-opening schools and early education centers in the whole country.

Simón Rodriguez Espinoza works and researches on leadership and school improvement as key focuses for the quality and equity of public education. Works as a senior consultant in the area of development and evaluation at Fundación Educacional Arauco. He is the coordinator of Desafío TEP, and collaborating with professional teams from different communes in the design and implementation of educational programs. Previously worked as coordinator and advisor in the Education Area of the Municipal Corporation of Villa Alemana. He has taught at the university level in initial teacher training programs and in continuing training programs for school leaders. He has been part of research teams with publications in books and journals. Simón Rodriguez has a degree in psychology from the Pontificia Universidad Católica de Valparaíso; a Master's degree in Leadership and Educational Management from the Alberto Hurtado University, Chile; and a student of Ph.D. in Education Universidad Diego Portales - Universidad Alberto Hurtado, Chile.

Open Access This chapter is licensed under the terms of the Creative Commons Attribution 4.0 International License (http://creativecommons.org/licenses/by/4.0/), which permits use, sharing, adaptation, distribution and reproduction in any medium or format, as long as you give appropriate credit to the original author(s) and the source, provide a link to the Creative Commons license and indicate if changes were made.

The images or other third party material in this chapter are included in the chapter's Creative Commons license, unless indicated otherwise in a credit line to the material. If material is not included in the chapter's Creative Commons license and your intended use is not permitted by statutory regulation or exceeds the permitted use, you will need to obtain permission directly from the copyright holder.

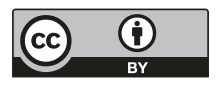

